E3S Web of Conferences 1, 14006 (2013)

DOI: $10.1051 / \mathrm{e} 3$ sconf/20130114006

(c) Owned by the authors, published by EDP Sciences, 2013

\title{
Thallium in mineral resources extracted in Poland
}

\author{
I. Bojakowska $^{1}$ and A. Paulo ${ }^{2}$ \\ ${ }^{1}$ Polish Geological Institute - National Research Institute, 00-975 Warszawa, POLAND, izabela.bojakowska@pgi.gov.pl \\ ${ }^{2}$ AGH University of Science and Technology, faculty of Geology, Geophisics and Environmental Protection, 30-059 \\ Krakow, Poland, andrzej.paulo@interia.pl
}

\begin{abstract}
Thallium concentrations in primary mineral commodities extracted in Poland and processed in high temperatures were determined by ICP-MS method. Samples of hard and brown coal, copper-silver and zinclead ores, argillaceous and calcareous rocks of different genesis and age were analyzed. The highest thallium concentrations occur in the zinc-lead ores, the average content being of $52.1 \mathrm{mg} / \mathrm{kg}$. The copper ores contain in average $1.4 \mathrm{mg} / \mathrm{kg}$ of thallium. Hard coals from the Upper Silesian Coal Basin display higher thallium content than those exploited in the Lublin Coal Basin. Brown coals from Turow deposit distinguish by much higher values, $0.7 \mathrm{mg} / \mathrm{kg} \mathrm{Tl}$, than those from huge Bełchatów and smaller Konin-Turek region deposits. Average thallium concentrations in clays used for ceramic materials are lower than $1 \mathrm{mg} / \mathrm{kg}$, except of Mio-Pliocene Slowiany deposit. The average content of thallium in the studied limestone and dolomite raw materials for cement, lime, and metallurgical flux, and refractories is very low in comparison to the average amounts in the world carbonate rocks.
\end{abstract}

Key words: thallium, pollution, coals, ores, argillaceous rocks, calcareous rocks

\section{Introduction}

Thallium metal and its compounds are regarded highly toxic element. Thallium accumulation in the organism destroys important parts of the cells and causes genetic changes of the embryo, disturbances in the heart-vessel, breathing and nerve systems, degeneration changes in the suprarenal glands, alopecia, damages in liver and kidneys as well as a loss of hearing, seeing and hair (Repetto et al. 1998, Seńczuk 2002). Thallium is a metal dispersed in the environment. Due to its ion radius, close to potassium and rubidium, it often substitutes these elements (mainly in feldspars and micas). It is a chalcophile element in the hydrothermal environment entering into sulphides (marcasite, pyrite, galena, sphalerite, antimonite, realgar) and sulphosalts (geochronite, boulangerite, jordanite), in amounts from traces to over $0.1 \%$. In the weathering zone and sedimentary rocks, thallium is bound by secondary minerals (e.g. jarosite, $\mathrm{Pb}$ jarosite), clay minerals as well as iron and manganese hydroxides (psylomelane contains up to $0.1 \% \mathrm{Tl}$ ) and the organic matter. Thallium element may be entirely easily emitted to the environment during high temperature production processes. It has low melting $\left(303.5^{\circ} \mathrm{C}\right)$ and boiling points $\left(1473^{\circ} \mathrm{C}\right)$ what results in its relative ability to be released to the environment. So smelting of zinc-lead concentrates, reduction of limonitic ironstones, coal burning, production of sulphuric acid and cement are main sources of the anthropogenic pollution with thallium.

\section{Materials and Methods}

Thallium concentrations were determined in different mineral resources exploited in Poland and processed in high temperatures. 112 Samples of hard coal from Carboniferous deposits of the Upper Silesian (USCB) and 29 samples from Lublin Coal Basins (LCB) were studied. Samples of Miocene brown coal were taken from Turów (25 samples), Bełchatów (42 samples), and 37 samples in total from Adamów, Lubstów, Kazimierz and Koźmin deposits. All exploited lithotypes of Lower Zechstein $\mathrm{Cu}-\mathrm{Ag}$ ore are represented by a total of 152 samples (Polkowice-Sieroszowice, Rudna, Lubin mines). Zinc and lead ores are represented by a total of 67 samples (Trzebionka mine near Chrzanów and Pomorzany mine near Olkusz). Analyzed samples of clay rocks represent the following genetic and stratigraphic kinds: ice-dammed clays and silts, tills, alluvial clays and muds, eolian loess clays, lacustrine and marine clays and silts as well as Jurassic and Triassic continental and epicontinental claystones. Individual clay deposits supplied 1-6 samples, depending on lithological variability. In total 178 samples of clay rocks from 41 deposits were analysed. Carbonate rocks - limestones 
and marls - were sampled in the deposits of wide span of ages. Individual deposits are represented by 4 up to 13 samples, depending on lithological variability. Total number of samples from carbonate rocks amounts to 137 .

The content of thallium was determined after complete dissolution in all studied samples of ores or coarse grained individual ore minerals, fossil fuels and rock raw materials by ICP-MS method using the Perkin Elmer equipment ELAN DERCII (USA)

\section{Results and Discussion}

Thallium content in Polish hard coals falls into the interval from $<0.2 \mathrm{mg} / \mathrm{kg}$ (detection limit) to $5.3 \mathrm{mg} / \mathrm{kg}$. Coals from the Upper Silesian Coal Basin display higher thallium content in comparison to the coals from Lublin Coal Basin. The average $\mathrm{Tl}$ contents are $0.5 \mathrm{mg} / \mathrm{kg}$ and $0.3 \mathrm{mg} / \mathrm{kg}$ in the Upper Silesian and Lublin coals respectively. The highest concentration was observed in the upper coal series of USCB, generally enriched in pyritic sulphur, i.e. in the Libiaz and Laziska Beds.

The thallium content in Polish brown coals oscillates from $<0,2$ to $2.4 \mathrm{mg} / \mathrm{kg}$. The coals from the Bełchatów deposit and small deposits from the Adamów-Konin region, i.e. Koźmin, Lubstów, Adamów, and Kazimierz are typically low in thallium; its content does not exceed $0.4 \mathrm{mg} / \mathrm{kg}$, and the average is below $0.2 \mathrm{mg} / \mathrm{kg}$. The coals from the Turów deposit distinguish themselves with a significantly higher thallium contents; their average equals to $0.7 \mathrm{mg} / \mathrm{kg}$. This enrichment may result from the alimentation of the coal basin by the material derived from granitoids of the crystalline basement and Tertiary volcanic rocks interfingering with the coal bearing formation.

Polish coals display lower Tl average concentrations in comparison to the published data on world deposits. For example, Virginia hard coals contain in average 1.2 $\mathrm{mg} / \mathrm{kg}$, and Brazilian $2 \mathrm{mg} / \mathrm{kg}$ (Kalkreuth et al., 2006; Kabata-Pendias and Mukherjee, 2007). Very high thallium contents exceeding $30 \mathrm{mg} / \mathrm{kg}$ are present in the coals from the Wulantuga deposit in China (Qi et al. 2007). Lignites from Turkish Kantal Basin display 4.2 to 8.0, in average $5.8 \mathrm{mg} / \mathrm{kg}$ thallium, and from Pond Creek, Kentucky, USA, up to $46 \mathrm{mg} / \mathrm{kg}$ in the upper seams (Karayigit et al., 2001; Hower et al., 2005). Otherwise, in the majority of the brown coal deposits, thallium is quite low, e.g. in the Turkish lignites the average thallium content is 0.14 $\mathrm{mg} / \mathrm{kg}$, while in coals from Xingren, Guizhou (China) $0.11 \mathrm{mg} / \mathrm{kg}$ (Gürrdal, 2008; Dai et al., 2006).

In copper ores thallium was found in concentration ranging from $<0.2$ to $17.9 \mathrm{mg} / \mathrm{kg}$. The average concentration in the copper-bearing shales is the highest, being much lower in the sandstones and carbonates. The shales contain in average $3.8 \mathrm{mg} / \mathrm{kg}$ of thallium, while dolomites and sandstones below $1 \mathrm{mg} / \mathrm{kg}$. The ores from Rudna mine contain in average of $0.9 \mathrm{mg} / \mathrm{kg}$, whereas from Polkowice-Sieroszowice and Lubin mines 1.4 and $1.5 \mathrm{mg} / \mathrm{kg}$, respectively. The average thallium concentration in copper-bearing shales is higher than that in the standard black shales $-2.0 \mathrm{mg} / \mathrm{kg}$ (Yudowich and Ketris, 1997); however it is lower than the value 8.3 $\mathrm{mg} / \mathrm{kg}$ in black shales given by Huyck (1990) and distinctly lower than in the metal-bearing shales, 16.6 $\mathrm{mg} / \mathrm{kg}$ (Huyck, 1990).

In zinc-lead ores thallium concentration ranges from below 0.2 to $550 \mathrm{mg} / \mathrm{kg}$. Its average concentration of $52.1 \mathrm{mg} / \mathrm{kg}$ is very high in comparison to the copper ores $(1.3 \mathrm{mg} / \mathrm{kg})$. The geometric mean $(9.8 \mathrm{mg} / \mathrm{kg})$ and median $(11.1 \mathrm{mg} / \mathrm{kg})$ are also high when compared with the corresponding values in the sedimentary rocks, especially in carbonates (average $0.1-1.4 \mathrm{mg} / \mathrm{kg}$, KabataPendias and Mukherjee, 2007). High thallium concentrations are characteristic for the ores from the Pomorzany mine (in average of $82.5 \mathrm{mg} / \mathrm{kg} \mathrm{Tl}$ ) in comparison to the Trzebionka mine (average 15.5 $\mathrm{mg} / \mathrm{kg}$ ). Studies on minerals (sphalerite, galena, marcasite) have proved that the higher thallium amounts (0.08-1.20\%) have been found in the metacolloidal pyrites, while in melnikovite $0.05 \%$ (Kucha and Jędrzejczyk, 1995; Sawłowicz, 1981). Much lower amounts of thallium occur in galena - up to $60 \mathrm{mg} / \mathrm{kg}$ (the average content of $13.2 \mathrm{mg} / \mathrm{kg}$ ) and sphalerite - up to $92 \mathrm{mg} / \mathrm{kg}$ (the average $26.5 \mathrm{mg} / \mathrm{kg}$ ). It can be concluded that the presence of thallium in $\mathrm{Zn}-\mathrm{Pb}$ ores and derived concentrates is connected first of all with the occurrence of the thallium-bearing polymorphs of iron sulphide.

Rock raw materials Thallium concentration in Polish clays subjected to high temperature processing ranges from $<0.2$ to $1.3 \mathrm{mg} / \mathrm{kg}$, its average amount is 0.7 $\mathrm{mg} / \mathrm{kg}$, the geometric mean $0.6 \mathrm{mg} / \mathrm{kg}$, the median 0.7 $\mathrm{mg} / \mathrm{kg}$. The average concentration in the studied deposits oscillated from $<0.2$ to $1.2 \mathrm{mg} / \mathrm{kg}$. Most thallium is contained in the Mio-Pliocene Poznan Clays in the Słowiany and Fordon deposits, while the lowest concentrations occur in Cretaceous kaolinite clays of Maria deposit, Miocene refractory clays of RuskoJaroszów deposit, Pleistocene loesses from Izbica and Triassic clays of Ligota Dolna deposit. The occurrence of the thallium in clay raw materials is probably due to a presence of relictic feldspars and micas, where thallium substitutes for potassium. The thallium may be occasionally combined by clay minerals or iron and manganese hydroxides, the organic matter as well. Our results fit the average concentration in the world claystones corresponding to the interval of $0.5-2 \mathrm{mg} / \mathrm{kg}$ Tl (Kabata-Pendias and Mukherjee, 2007) but seem to be a bit lower; only in Słowiany deposit the content averages $1.2 \mathrm{mg} / \mathrm{kg}$ breaking the level of $1 \mathrm{mg} / \mathrm{kg}$. In the clays of greater importance for construction ceramics in Poland, i.e. Pleistocene ice-dammed clays and Neogene Poznań and Krakowiec series, the average thallium content is the same $-0.7 \mathrm{mg} / \mathrm{kg}$ (table 2). These rocks display also similar potassium contents (Nieć and Ratajczak, 2004), that may point to the distinct thallium relation with potassium-bearing feldspars and layered minerals. The correlation of thallium and iron compounds, which are ubiquitous in clay rocks may be of lesser importance.

In carbonate rocks thallium concentration ranges from $<0.2$ to $0.8 \mathrm{mg} / \mathrm{kg}$, its arithmetic average being 0.2 $\mathrm{mg} / \mathrm{kg}$, while the median and geometric means are below $0.2 \mathrm{mg} / \mathrm{kg}$. The average amounts of the thallium in individual deposits studied were most frequently lower 
Table 1. Statistical parameters of thallium in Polish mineral resources $(\mathrm{mg} / \mathrm{kg})$

\begin{tabular}{|l|rrrrr|}
\hline Mineral resource and its source & $\begin{array}{c}\text { Arithmetic } \\
\text { mean }\end{array}$ & $\begin{array}{c}\text { Geometric } \\
\text { mean }\end{array}$ & Median & Minimum & Maximum \\
\hline Hard coal & 0.5 & 0.2 & 0.2 & $<0.2$ & 5.3 \\
USCB (n=112) & 0.5 & 0.2 & 0.2 & $<0.2$ & 5.3 \\
Lublin CB (n=29) & 0.4 & 0.3 & 0.3 & $<0.2$ & 2.8 \\
\hline Brown coal & 0.3 & 0.2 & $<0.2$ & $<0.2$ & 2.4 \\
Bełchatów mine (n=42) & $<0.2$ & $<0.2$ & $<0.2$ & $<0.2$ & 0.4 \\
Turów mine (n=29) & 0.7 & 0.6 & 0.6 & $<0.2$ & 2.4 \\
Konin-Turek district (n=37) & $<0.2$ & $<0.2$ & $<0.2$ & $<0.2$ & 0.4 \\
\hline Copper ores & 1.3 & 0.7 & 0.8 & $<0.2$ & 17.9 \\
Polkowice-Sieroszowice min (n=47) & 1.4 & 0.8 & 0.9 & $<0.2$ & 17.9 \\
Rudna mine (n=58) & 0.9 & 0.5 & 0.6 & $<0.2$ & 6.2 \\
Lubin mine (n=47) & 1.5 & 1.0 & 0.9 & $<0.2$ & 9.4 \\
shales (n=25) & 3.8 & 2.9 & 2.8 & 0.9 & 17.9 \\
dolomite (n=78) & 0.6 & 0.5 & 0.5 & $<0.2$ & 2.3 \\
sandstone (n=49) & 0.9 & 0.8 & 0.9 & $<0.2$ & 2.7 \\
\hline Zinc-lead ores & 52.1 & 9.8 & 11.1 & $<0.2$ & 547.4 \\
Pomorzany mine (n=38) & 82.5 & 36.4 & 39.2 & 1.8 & 547.4 \\
Trzebionka mine (n=29) & 15.5 & 2.0 & 1.9 & $<0.2$ & 233.5 \\
\hline Clay resources & 0.7 & 0.6 & 0.7 & $<0.2$ & 1.3 \\
Ice-dammed (n=27) & 0.7 & 0.7 & 0.8 & 0.4 & 1.0 \\
Krakowiec series (n=10) & 0.7 & 0.7 & 0.7 & 0.6 & 0.7 \\
Poznan series (n=41) & 0.8 & 0.7 & 0.7 & 0.4 & 1.3 \\
\hline Carbonate rocks & 0.2 & $<0.2$ & $<0.2$ & $<0.2$ & 0.8 \\
Cretaceous (n=18) & 0.2 & 0.1 & 0.1 & 0.1 & 0.4 \\
Jurassic (n=52) & 0.1 & 0.1 & 0.1 & 0.1 & 0.3 \\
Devonian (n=25) & 0.2 & 0.2 & 0.1 & 0.1 & 0.8 \\
Cambrian (n=14) & 0.1 & 0.1 & 0.1 & 0.1 & 0.5 \\
\hline
\end{tabular}

than $0.2 \mathrm{mg} / \mathrm{kg}$. Slightly higher values are characteristic for the Devonian limestones in Kowala and Nowiny deposits, and dolomites in Dubie quarry. The average thallium concentration in the world carbonate rocks corresponds to the interval of $0.01-1.5 \mathrm{mg} / \mathrm{kg}$ (KabataPendias and Mukherjee, 2007). The mean amounts of thallium in the studied carbonate rocks are generally below $0.2 \mathrm{mg} / \mathrm{kg}$, therefore distinctly lower then average world values. Low thallium concentrations in Polish calcareous raw materials remain in contradiction to the data published in different papers on environmental geochemistry, which point to the cement industry as important thallium emission source. The source of thallium in emissions from the cement works seems to be not the calcareous rock but the coal used as a fuel there. Other possible sources are burning of thallium-containing wastes or adding pyrite-bearing carbonate wastes from ore mines.

\section{Conclusion}

1. Thallium is a toxic element disseminated in the environment in trace amounts and usually bound in insoluble minerals resulting in its relative immobility. The extraction of mineral resources and high temperature processes applied to resulting raw materials bring about to increased content of thallium in surficial layers and formation of potentially dangerous compounds.

2. The highest thallium concentrations occur in the zinc-lead ores, the average content being of $52.1 \mathrm{mg} / \mathrm{kg}$. The ores from Pomorzany mine (average $82.5 \mathrm{mg} / \mathrm{kg}$ ) are richer in thallium than those from Trzebionka mine (average $15.5 \mathrm{mg} / \mathrm{kg}$ ). The copper ores contain in average $1.4 \mathrm{mg} / \mathrm{kg}$ of thallium, among them shale ores $3.8 \mathrm{mg} / \mathrm{kg}$, while carbonate and sandstone ores contain below $1 \mathrm{mg} / \mathrm{kg}$ of thallium.

3. Hard coals from the Upper Silesian Coal Basin display higher thallium content than those exploited in the Lublin Coal Basin. The highest thallium concentration occurs in the seams of Libiaz and Laziska beds, occupying an upper portion of the USCB profile. Brown coals from large Bełchatów deposit and smaller one in Konin-Turek region show low thallium concentration not exceeding 0.4 $\mathrm{mg} / \mathrm{kg}$, while the average is below $0.2 \mathrm{mg} / \mathrm{kg}$. Brown coals from Turow deposit distinguish by much higher values, 0.7 $\mathrm{mg} / \mathrm{kg} \mathrm{Tl}$.

4. Average thallium concentrations in clays used for ceramic materials are lower than $1 \mathrm{mg} / \mathrm{kg}$, except of MioPliocene clays from the Slowiany deposit. In ice-dammed Pleistocene clays, as well as in the Poznan and Krakowiec clays, the average equals to $0.7 \mathrm{mg} / \mathrm{kg}$.

5. The average amount of thallium in the studied calcareous raw materials used for manufacturing portland cement, lime and as a flux in iron and steel metallurgy is very low in comparison to the average amounts in the 
world carbonate rocks. Analyzed carbonate rocks contain generally below $0.2 \mathrm{mg} / \mathrm{kg} \mathrm{Tl}$. Only limestones from the Kowala and Nowiny, and dolomites from the Dubie deposits are relatively enriched in this element.

\section{Acknowledgements}

Present studies were financed by Polish Ministry of Science and Higher Education (project T 12 BO74 28).

\section{References}

Dai S, Zeng R, Sun Y. Enrichment of arsenic, antimony, mercury, and thallium in Late Permian anthracite from Xingren, Guizhou, Southwest China. International Journal of Coal Geology 2006; 66:217-226.

Gürrdal G. Geochemistry of trace elements in Çan coal (Miocene), Çanakkale, Turkey. International Journal of Coal Geology 2008; 74:28-49.

Huyck HLO. When is a metalliferous black shales not a black shale? U. S. Geol. Surv. Circ., 1990; 1058: 42-56.

Hower J, Ruppert L, Eble C, Clark W. Geochemistry, petrology, and palynology of the Pond Creek coal bed, northern Pike and southern Martin counties, Kentucky. International Journal of Coal Geology 2005; 62 (3): 167-181.

Karayigit A, Gayer R, Ortac F, Goldsmith S. Trace elements in the lower Pliocene fossiliferous Kangal Lignites, Sivas, Turkey. International Journal of Coal Geology 2001; 47 (2): 73-89.

Kabata-Pendias A, Mukherjee A. Trace elements from soil to human. Springer. 2007.

Kalkreuth, W., Holz, M., Kern, M., Machado, G., Mexias, A., Silva, M. B. Petrology and chemistry of Permian coals from the Paraná Basin: 1. Santa Terezinha, Leão-Butiá and Candiota Coalfields, Rio Grande do Sul, Brazil. International Journal of Coal Geology, 2006; 68, 79-116.

Kucha H., Jędrzejczyk B. Primary minerals of mining and metallurgical $\mathrm{Zn}-\mathrm{Pb}$ dumps at Bukowno, Poland, and their stability during weathering. Miner. Polonica, 1995; 26 (2): 75-93.

Nieć M., Ratajczak T.: Złoża kopalin ilastych do produkcji ceramiki budowlanej, kruszyw lekkich i cementu. W: Surowce skale. Surowce ilaste. Wydawnictwo Instytutu GSMiE PAN, Kraków, 2004.

Repetto G., Del Peso A., Repetto M. Human thallium toxicity. [In:] Thallium in the Environment. Nriagu J.O. (ed.). J. Wiley Series „Advances in Environmental Science and Technology", 1998; 29: $167-200$.

Qi H., Hu R., Hang Q. Concentration and distribution of trace elements in lignite from the Shengli Coalfields. Inner Mongolia, China: implication on origin of the associated Wulantuga Germanium Deposit. International Journal of Coal Geology 2007; 71:129. 152.

Yudovich YE, Ketris MP Geochemistry of black shales. Prolog Publisher, Syktyvkar 1997.

Seńczuk W. Toksykologia. PZWL. Warszawa 2002.

Sawłowicz Z. Forma występowania domieszek Pb, As, Tl i Zn w pirycie ze złóż śląsko -krakowskich. Rudy i Metale Nieżelazne 1998; 26, 7: 355-362. 